\title{
Analysis on the Online Purchasing Behavior of Chinese Customers
}

\author{
Zihan $\mathrm{He}^{1, \mathrm{a}}$ \\ Shiyan High School International Department, Shenyang, Liaoning, 110000, China \\ Corresponding author's e-mail: angela@cas-harbour.org
}

\begin{abstract}
With the increasing number of online shoppers, the ways that people shop are changed significantly. Researchers and store planners have acute interests in the customers purchasing behavior on online stores, and the reason that increasingly number of people prefer online shopping. The survey was done in China, mainly analyzing the purchasing behavior of online customers in China. The survey collected the information of Chinese people's purposes of choosing shopping channel, Chinese customers preference on buying certain products online, and the elements that will affect customers' shopping feelings. T-test has been done to analyze the significance of the data and information.

The survey provides the findings of Chinese customers' general trend of the purposes, products, and the elements that they care when shopping online. Meanwhile, the survey also analyzes an important finding of the relationship gender, products, and the elements that people care during shopping.

Because of the participants, this article gives many information and knowledge about the Chinese people's shopping behavior and preferences; this article could also be used as a reference for online businesses.
\end{abstract}

Keywords: Chinese customers, purchasing behavior, online, offline, gender

\section{INTRODUCTION}

The emerge of e-commerce has greatly change people's perspective of shopping and shopping channels. E-commerce is a name for online retailers who sell goods and provide services through the online channel or computer networking. As one of the most developed country in e-commerce, the number of money Chinese contributed to e-commerce is still increasing recently. According to Pew Research in 2019, Chinese people spent more than 3,161,000,000RMB on online shopping in 2018. China's online shopper increased 53 million, from 516 million to 569 million within 12 months. Besides the traditional physical shopping system, the newly shopping channel is e-commerce, which are names for the system that online retailers who sell goods and provide services through the online channel or computer networking, and the physical store commerce. E-commerce can be divided into: E-tailing or "virtual storefronts"with catalog online or sometimes gathered into "virtual storefronts.

According to the previous survey, the more individuals spend time online, the more likely they will purchase goods from online stores. Online searching promotes online shopping [3], because online search engines play an essential role in providing links of the products. Other elements like the convenience, services, and prices [5] could also affect people's choices about shopping channels. Consumers are more willing to trust their own past experiences or the other people who were used to consumed. E-commerce provides a really good opportunity to the shoppers by allowing them to compare similar goods from different stores and provide the consumers' experiences transparently [4]. Online customers also be divided into five kinds of motive-based groups according to a previous survey [1], convenience-oriented shoppers, demanding-oriented shoppers, accommodated shoppers, apathetic shoppers, and technology-oriented shoppers. Nevertheless, with the development of transportation system, the convenience, as a major advantage and character of online shopping, is decreasing in customers' consideration; even some people in the survey indicated that get out of the house and get some exercise while shopping is beneficial[2].

Many previous studies about the customers' purchasing behavior focus mainly on the whole population include all countries, all age range, which are lack of the specific target groups. This paper will include the survey of customer purchasing behavior of Chinese among different age groups.

\section{DESIGN OF THE QUESTIONAIRE}

There were 257 participants from more than 30 cities and more than 10 provinces in China filled the questionnaire during the data collection period, including 49 teenagers and 208 adults.

The questionnaire includes 11 questions in order to get the basic information of the participants and their intentions, preference, motives, and habits in their daily purchasing 
processes.

The questionnaires were conducted online and mainly distributed in Wechat and Wechat moment, www.sojump.com is a website used to upload the questionnaire on the website and transform the questionnaire into online format, a small proportion of them were printed and handed out in two communities located in two cities. The summary table of all the participants in this survey is shown below.

Table1. Demographic information of participants.

\begin{tabular}{|c|c|c|c|c|c|c|c|c|c|c|}
\hline \multicolumn{2}{|c|}{ Gender } & \multicolumn{2}{|c|}{ Age } & \multicolumn{6}{c|}{ Job } \\
\hline Male & Female & $<25$ & $\geq 25$ & Self-employed & Free & Manage & normal & other & student & unemployed \\
\hline 81 & 176 & 67 & 190 & 12 & 9 & 36 & 114 & 12 & 61 & 10 \\
\hline
\end{tabular}

\section{FINDINGS AND DISCUSSIONS}

In the tables, $*$ indicates significance at $10 \%$ level; $* *$ indicates significance at $5 \%$ level; $* * *$ indicates significance at $1 \%$ level. In all the findings, only difference bigger than 0.05 in mean was consider a difference.

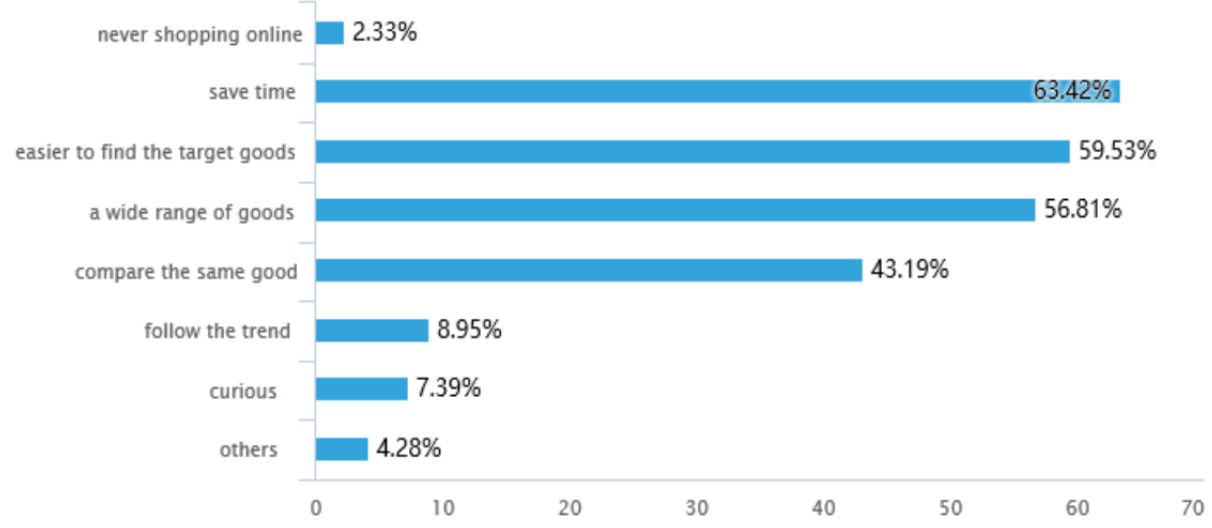

Figure 1. The purpose of shopping online.

This figure reveals that the top three elements that attract customers to choose online stores are time saving, easier to find the target goods, and online stores have a wide range of products. Among the participants who chose "others",

\subsection{Findings and discussion about purposes}

The purposes of Chinese people choosing online shopping is shown in the figure below.

\subsection{Findings and discussion about products}

most of the answers are that the products in the online stores are generally cheaper than the same products in the offline stores.
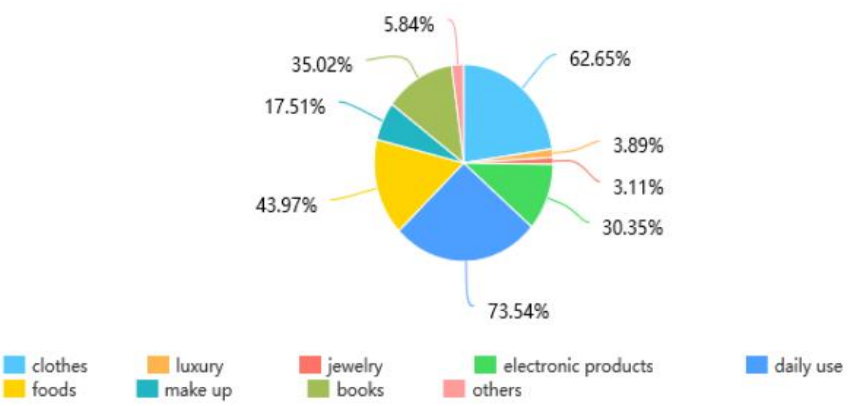


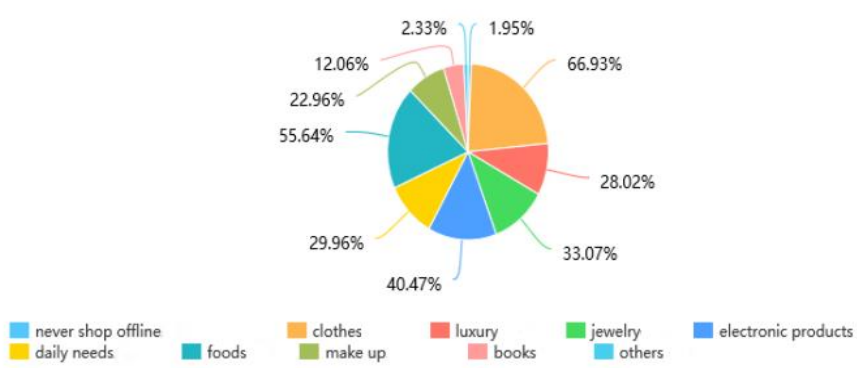

Figure 2. The main products that Chinese customers buy both online and offline.

Combine with the analyzes of the figure two, the primary reasons for people choosing offline stores are the quality examination, try and feel goods, and the changing and refunding services, this explain the reason that the consumption of luxuries and jewelries in offline stores increase significantly.

\subsection{Findings and discussion about the elements that will affect customers' choices during the shopping process}

The elements that affect customers' choices both online and offline are shown in the figures and table below.

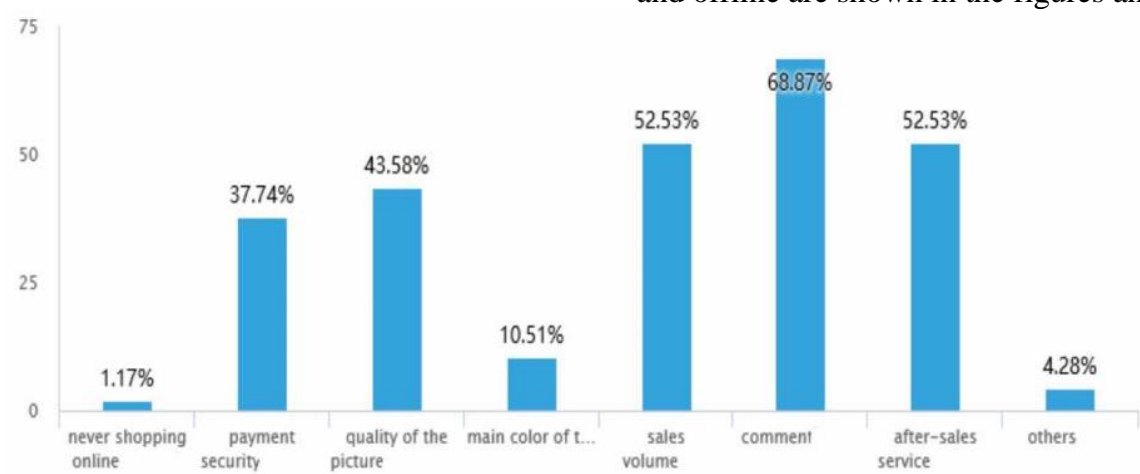

Figure 3. Elements affect customers' choices online.

As the figure reveals that the most significant elements in shaping customers' feelings and choices are the comments from the previous customers, sales volume, and the after-sales service of the online stores.

In the "others" option, the most popular answer is whether the pictures of the products are conforming with the real products, which is also the elements related to the quality of the picture. Therefore, the quality of picture that the online retailers post online is also a main factor that would shape the customers' feelings and choices of the stores.

\subsection{Findings and discussions about the relationship between gender and choices}

Table 2. The relationship between gender and the preferred online product.

\begin{tabular}{|c|c|c|c|c|c|c|c|c|}
\hline & cloth & luxury & Daily-use & Electronic & foods & books & makeup & others \\
\hline Female & $68 \%$ & $5 \%$ & $64 \%$ & $19 \%$ & $15 \%$ & $35 \%$ & $16 \%$ & $6 \%$ \\
\hline Male & $52 \%$ & $2 \%$ & $44 \%$ & $52 \%$ & $27 \%$ & $35 \%$ & $1 \%$ & $5 \%$ \\
\hline
\end{tabular}

Note: The choice of jewelry is deleted from the analyzing table is because no male chose the option of "jewelry".

The table reveals that most of the male customers preferred buying electronic products and foods online. Whereas, female customers buy daily uses and makeups much more than male customers do. The percentage of participants' 
choices of the products that they love to buy from online stores in the gender that they belong to was analyzed. The Chi-Squared Value is below the significant value, so the choices of the preferred products online of each gender have significant differences.

Table 3. Relationship between gender and the elements that customers care when shopping online.

\begin{tabular}{|c|c|c|l|c|c|c|l|l|}
\hline & $\begin{array}{l}\text { never } \\
\text { online }\end{array}$ & Payment & Quality of & Store color & Sale volume & comment & after-sale & others \\
\hline Female & $1 \%$ & $40 \%$ & $48 \%$ & $10 \%$ & $43 \%$ & $41 \%$ & $34 \%$ & $3 \%$ \\
\hline Male & $1 \%$ & $32 \%$ & $33 \%$ & $11 \%$ & $47 \%$ & $40 \%$ & $31 \%$ & $5 \%$ \\
\hline
\end{tabular}

The result of the figure shows that the biggest differences between male and female customers care when shopping online is the quality of the products' pictures. In most people's mind, male and females care exactly different elements when shopping online. In the data analysis part, the gender and the elements that will affect customers' feelings and choices of online stores has been analyzed. The Chi-Squared value is above the significant value, so the elements that male and female customers care while shopping do not have much difference.

The surprising finding of the results from the table 2 and the table 3 is that even though the male and female's preference on the products is significantly different when shopping online, the elements that the customers care about are nearly the same.

Table 4. The relationship between gender and the reasons customers love shopping online.

\begin{tabular}{|c|c|c|c|c|c|c|c|}
\hline & Seldom shop & Save & Find target & Wide range & Follow the & curious & Compare the \\
online & time & goods & & & & & same goods \\
\hline Female & $2 \%$ & $67 \%$ & $56 \%$ & $57 \%$ & $8 \%$ & $7 \%$ & $44 \%$ \\
\hline Male & $4 \%$ & $56 \%$ & $67 \%$ & $57 \%$ & $11 \%$ & $9 \%$ & $41 \%$ \\
\hline
\end{tabular}

Chi-Square Value: 0.351574573

Table 5. The relationship between gender and the reasons customers love shopping offline.

\begin{tabular}{|c|c|c|c|c|c|c|}
\hline & $\begin{array}{l}\text { Quality } \\
\text { examination }\end{array}$ & $\begin{array}{l}\text { Changing } \\
\text { service }\end{array}$ & $\begin{array}{l}\text { Payment } \\
\text { service }\end{array}$ & $\begin{array}{l}\text { Able to try } \\
\text { goods }\end{array}$ & $\begin{array}{l}\text { Service of } \\
\text { salespeople }\end{array}$ & others \\
\hline Female & $65 \%$ & $43 \%$ & $26 \%$ & $52 \%$ & $25 \%$ & $5 \%$ \\
\hline Male & $72 \%$ & $44 \%$ & $23 \%$ & $58 \%$ & $35 \%$ & $1 \%$ \\
\hline
\end{tabular}

Combining the table 6 with table 7, the percentages of the female and male customers' reasons to choose online stores or offline stores explain the reason that even though male and female care choose different products to buy 
during the shopping process, all customers still care about the same things. In the online and offline purposes, the chi-square value do not show an extremely big differences.

\section{CONCLUSION}

Even though e-commerce is a very popular and developed business system in China nowadays and many previous studies have analyzed the purchasing behavior of world-wide a lot, the previous studies about Chinese e-commerce are very limited. This paper has generated many useful findings for both shopping research and the online businesses, the products that people usually purchase, and the elements that people care when shopping online.

The purpose of the customers: for most online customers, convenient is the most important reason to support their choice. Other elements like easy to find the target goods and the kinds of products are various are also the popular reasons for the online shoppers. The least popular choice is to follow the fashion trend. For online stores, female customers will still pay a lot of attention on the payment security. Whereas, the security is no more the reason that make online customers worry, because online stores have developed the systematic paying system now.

The products: people like to buy foods, daily-use, and clothes in both online stores. Whereas, electronic products are extremely popular for male customers in the online stores. People seldom go to the online stores to buy jewelries and luxuries.

The elements that customers care: the results show that male customers actually care more about the color and the design of the store than female customers do. People care the design and the color of the store much more when they shop offline than online. The findings reveal that for both male and female customers, sale volume and the comments of the previous buyers are the essential factor to be considered. The quality of the products' pictures also plays an important role in attracting the customers.

The findings could give the business people many suggestions on how to operating the stores well. For the online stores, the retailers need to organize a well-developed and well-aligned comment list. The pictures of the products should be in the comfortable condition. The style of the online stores should not follow the fashion trend because curious and follow the trend attract the least people in the survey. Clothes, foods, and daily-uses have the considerable prospect in the future online market. There is also much other information in this survey that can provide implication to people who just want to sell some things and this survey will definitely be useful to all the many merchants and businesses in the future.

\section{ACKNOWLEDGMENT}

First and foremost, I would like to show my deepest gratitude to my teachers and professors in my university, who have provided me with valuable guidance in every stage of the writing of this thesis. Further, I would like to thank all my friends and roommates for their encouragement and support. Without all their enlightening instruction and impressive kindness, I could not have completed my thesis.

\section{REFERENCES}

[1] Ha, S. \& Stoel, L. (2010) E-tail Evolution: Motives and Behavioral Intentions of E- shopper Segments, Journal of Global Fashion Marketing: Bridging Fashion and Marketing, $1(1), \quad 9-18, \quad$ DOI: 10.1080/20932685.2010.10593053

[2] Mary C. Gilly \& Mary Wolfinbarger (2000) A comparison of consumer experiences with online and offline shopping. Consumption Markets \& Culture, 4(2), 187-205, DOI: 10.1080/10253866.2000.9670355

[3] Xi, G., F. Zheng, X. Cao, \& Xu, F. (2018). Empirical evidence from Nanjing, China. The interaction between e-shopping and store shopping. Transportation Letters. DOI: $10.1080 / 19427867.2018 .1546797$

[4] Xiong, Y. M., \& Zhang, Y.Y. (2018). Analysis of influence factors of customer loyalty under e-commerce environment. Journal of Discrete Mathematical Sciences and Cryptography, 21(6),1455-1460. DOI: 10.1080/09720529.2018.1527814

[5] You, Q., W. Chen, \& Liu, K. (2014). The online shopping change the retail business model: A survey of the people use online shopping in China. IOSR Journal of Business and Management, 15(5), 77-110. Retrieved from www.iosrjournals.org 